\title{
Local-scale variation in trace elemental fingerprints of the estuarine bivalve Austrovenus stutchburyi within and between estuaries
}

\author{
C. R. Norrie ${ }^{1, *}$, B. J. Dunphy ${ }^{1,2}$, J. A. Baker ${ }^{3}$, C. J. Lundquist ${ }^{1,4}$ \\ ${ }^{1}$ Institute of Marine Science, University of Auckland, Auckland, New Zealand \\ ${ }^{2}$ School of Biological Sciences, University of Auckland, Auckland, New Zealand \\ ${ }^{3}$ School of Environment, University of Auckland, Auckland, New Zealand \\ ${ }^{4}$ National Institute of Water and Atmospheric Research (NIWA), Hamilton, New Zealand
}

\begin{abstract}
Trace elemental fingerprinting has been used to estimate population connectivity of marine species by using variations in the chemistry of shell produced in different water masses to determine the natal location of settlers. This method has been successfully used to differentiate between estuaries and coasts at spatial scales of $10 \mathrm{~s}$ to $100 \mathrm{~s}$ of $\mathrm{km}$. Here, we investigated the suitability of trace elemental fingerprinting to distinguish subpopulation connectivity at management scales suitable for local fishery or conservation management. The trace element chemistry of Austrovenus stutchburyi shells was used to distinguish between intra- and inter-estuary subpopulations at local $(\sim 1$ to $10 \mathrm{~km})$ scales, with $\sim 99 \%$ success. Differences between 8 locations within a large harbour and 4 smaller neighbouring estuaries were detected. $\mathrm{Sr}: \mathrm{Ca}, \mathrm{Zn}: \mathrm{Ca}$ and $\mathrm{Mn}: \mathrm{Ca}$ elemental ratios were the primary drivers of inter-site trace elemental fingerprint differences. Intra-shell variation in elemental fingerprints was used to examine temporal stability and demonstrated that, although intra-shell differences were present, site-specific differences in elemental fingerprints were maintained. The results of this study suggest trace elemental fingerprinting can be a viable method to estimate population connectivity over small inter- and intra-estuary spatial scales.
\end{abstract}

KEY WORDS: LA-ICP-MS · Microchemistry $\cdot$ Larval dispersal $\cdot$ DFA

\section{INTRODUCTION}

Population connectivity occupies a central role in population dynamics (Cowen \& Sponaugle 2009, Kool et al. 2013) and is relevant to marine management activities, including controlling the spread of invasive species, tracking species range shifts due to changing temperatures, marine reserve design and restoration efforts (Almany et al. 2009, Delaney et al. 2012, Kim et al. 2013, Sorte et al. 2013). The life history of many marine species consists of a pelagic larval phase which is capable of being transported distances rang-

\footnotetext{
*Corresponding author: cnor412@aucklanduni.ac.nz
}

ing from a few metres to 1000s of km (Grantham et al. 2003, Shanks 2009). When mature individuals exhibit no or limited mobility, this larval phase is critical to population connectivity (Largier 2003).

Quantifying the dispersal of marine larvae, however, is extremely difficult. Although artificial tagging techniques have met with some degree of success (Jones et al. 2005, Moran \& Marko 2005), propagules are subject to significant mortality, advection and diffusion processes over large scales, which makes the recapture of tagged individuals unlikely (Levin 2006, Gawarkiewicz et al. 2007). While examination of the

() The authors 2016. Open Access under Creative Commons by Attribution Licence. Use, distribution and reproduction are unrestricted. Authors and original publication must be credited. 
genetic structure of populations can be used to resolve broad-scale connectivity patterns, the temporal scale over which information can be obtained limits the applicability of these methods to local-scale management (Hedgecock et al. 2007, Ross et al. 2012).

Geochemical fingerprinting methods have considerable promise for overcoming the problems previously associated with tracking marine larvae. These techniques take advantage of natural variations in multi-elemental signals in carbonate structures (trace elemental fingerprints) accreted in geographically and chemically distinct water masses (e.g. Becker et al. 2005, Carson 2010, Sorte et al. 2013, Cathey et al. 2014). If larval calcified structures are metabolically inert, are formed in the natal water mass and are retained after settlement, their chemical signatures can be used to infer the origin(s) of individuals (Walther \& Thorrold 2006, Becker et al. 2007). The major advantage this methodology has over other techniques is that all members of a population potentially carry markers of larval origins. Bivalves are ideal candidates for the use of trace elemental fingerprinting, as the larval shell (prodissoconch) forms within $24 \mathrm{~h}$ of the veliger larva hatching, and juveniles subsequently retain their prodissoconch after settlement (Moueza et al. 2006).

Prior to the application of trace elemental fingerprinting techniques to track the dispersal of marine larvae, it is essential that the spatial resolution at which sites can be distinguished from each other is established (Campana et al. 2000, Gillanders et al. 2001, Becker et al. 2005). To date, individuals collected from sites located at distances ranging from $\sim 1$ to $>200 \mathrm{~km}$ have been able to be differentiated based on their trace elemental fingerprints (Dunphy et al. 2011, Cathey et al. 2014). Most studies have focused on establishing variation in trace elemental fingerprints over open coastlines or between closely located estuaries (e.g. Cathey et al. 2012, Sorte et al. 2013). In estuarine species, both biophysical models and empirical studies suggest that a large portion of larvae may be retained within the natal estuary (Lundquist et al. 2009, Peteiro \& Shanks 2015). Given that many species exhibit a patchy distribution within estuaries (Thrush et al. 2003), intra-estuary dispersal over small scales $(\mathrm{km})$ may be more relevant to the management of populations than interestuary dispersal.

Elements responsible for successfully discriminating individuals collected from different sites vary based on the species investigated, the area over which samples were collected and the time of sampling (Cathey et al. 2012, Carson et al. 2013, Sorte et al. 2013). Nevertheless, there are some elements which are commonly used to differentiate between individuals including $\mathrm{Mg}, \mathrm{Cr}, \mathrm{Mn}, \mathrm{Co}, \mathrm{Cu}, \mathrm{Zn}, \mathrm{Sr}, \mathrm{Cs}$, $\mathrm{Ba}, \mathrm{Pb}$, and $\mathrm{U}$ (Carson et al. 2007). Identifying which elements contribute to variation in elemental fingerprints for a species of interest can allow for an optimal elemental suite to be selected for analysis, which enhances analytical throughput, therefore reducing costs (Dunphy et al. 2011).

The use of multiple complementary techniques may provide a more holistic understanding of larval dispersal than can be achieved using one method alone (Abaunza et al. 2008, Tanner et al. 2016). In this study, we investigated elemental fingerprinting in a region where biophysical larval tracking models have already been developed to predict larval dispersal and population connectivity of estuarine bivalves (Lundquist et al. 2009, Lundquist \& Broekhuizen 2012). In addition to biophysical models existing in the area studied, the genetic structure of bivalve populations throughout New Zealand has been previously examined (Ross et al. 2012). The large scales of genetic population differentiation (>100 km), however, have limited applicability for local management of shellfish populations.

The primary objective of this study was to examine the spatial scale at which geochemical methods (i.e. trace elemental fingerprinting) can be used to differentiate between individuals of the bivalve Austrovenus stutchburyi. Small-scale (1 $\mathrm{km}$ to $10 \mathrm{~s}$ of $\mathrm{km})$ differences both within a single estuary and between closely located estuaries were examined. Intra-shell differences in elemental fingerprints were examined to determine if temporal variation in shell chemistry existed over the period of shell accretion. In addition, the trace element (TE) analytical suite which provided optimal classification success rates was determined to optimise future studies in this area.

\section{MATERIALS AND METHODS}

\section{Study species}

The New Zealand cockle Austrovenus stutchburyi is abundantly distributed within intertidal sand and mudflats in estuaries throughout New Zealand (Morton \& Miller 1968). Spawning typically occurs in the warmer summer months, with peak spatfall previously observed in Whangarei Harbour between December and February (Lundquist \& Broekhuizen 
2012). The dispersal period lasts 2 to $3 \mathrm{wk}$, after which settlement occurs at a size of approximately $180 \mu \mathrm{m}$ (Stephenson \& Chanley 1979). The shell of infaunal bivalves is entirely composed of aragonite, with calcite not being deposited (Green et al. 2013). In addition to larval dispersal processes, there is evidence of post-settlement dispersal, with juveniles $(<5 \mathrm{~mm})$ being found in the water column and in the bedload as well as adults being observed burrowing through the sediment (Cummings et al. 1995, Hewitt et al. 1996, Lundquist et al. 2004).

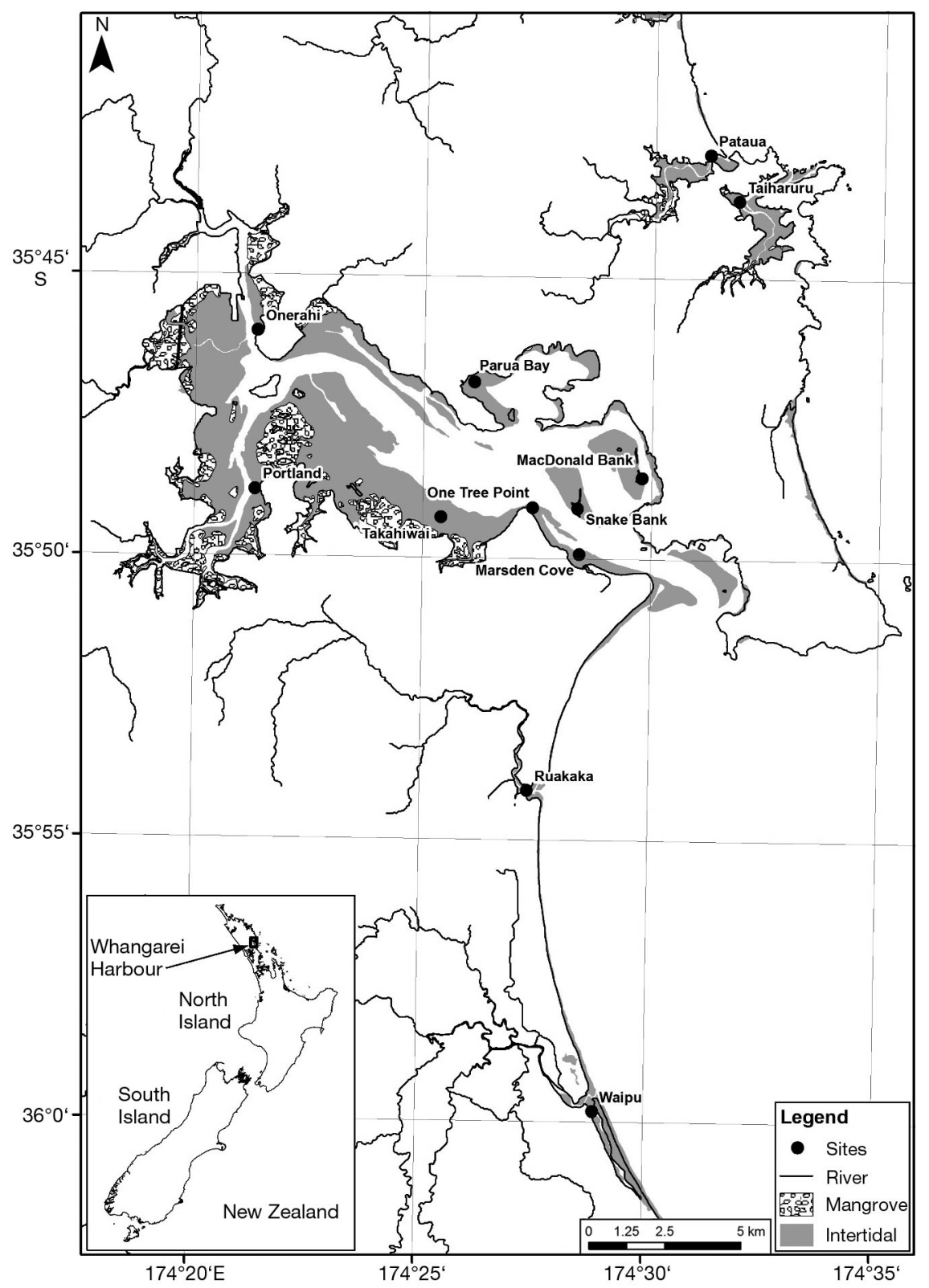

Fig. 1. Study area showing the sites sampled for Austrovenus stutchburyi. Shaded areas indicate intertidal regions within the estuaries

\section{Study site}

Whangarei Harbour (Fig. 1) is located in the northeast of New Zealand $\left(35^{\circ} 48^{\prime} \mathrm{S}, 174^{\circ} 26^{\prime} \mathrm{E}\right)$, covers an area of approximately $102 \mathrm{~km}^{2}$ at high tide and is approximately $24 \mathrm{~km}$ in length. The harbour consists of $54 \mathrm{~km}^{2}$ of intertidal flats and includes a range of habitats such as mangrove forests, seagrass meadows, shellfish beds, and intertidal mud and sandflats (Morrison 2003). The harbour receives runoff from a catchment area which is approximately $300 \mathrm{~km}^{2}$ in area (Griffiths 2012). The land use in the catchment is highly varied and includes urban inputs from Whangarei urban areas (10\%), indigenous forest $(20 \%)$, plantation forestry $(10 \%)$ and high-productivity agricultural grassland (50\%) (Griffiths 2012). The majority of freshwater input is from the Hātea River, located in the upper reaches of the harbour, which has a mean flow of $10 \mathrm{~m}^{3} \mathrm{~s}^{-1}$ (Inglis et al. 2006).

Whangarei Harbour supports a significant commercial, recreational and traditional fishery of A. stutchburyi, with commercial efforts restricted to Snake Bank (Williams et al. 2006). There has been interest in the restoration of historically important A. stutchburyi populations in recent years (Cummings et al. 2007, Lundquist et al. 2009, Hewitt \& Cummings 2013). These efforts have focused on the Takahiwai and Parua Bay sites (Fig. 1). There are a number of smaller estuaries located to the north and south of Whangarei Harbour which also support $A$. stutchburyi populations. Hydrodynamic models predict that larvae are highly connected within the harbour as well as being exported from the harbour to the adjacent coastline, promoting inter-estuary exchange (Lundquist et al. 2009, Lundquist \& Broekhuizen 2012).

\section{Sample collection}

Animals were collected in the first week of March 2014 from 8 sites 
located within Whangarei Harbour and from 2 estuaries located to the north and 2 located to the south along the same stretch of coast (Fig. 1). All A. stutchburyi were collected $2 \mathrm{~h}$ either side of low tide by excavating the upper $5 \mathrm{~cm}$ of the sediment surface with a plastic trowel and sieving this sediment through 2 stacked plastic sieves with a mesh size of 10 and $2 \mathrm{~mm}$. The contents of the $10 \mathrm{~mm}$ sieve were discarded, and all A. stutchburyi were picked out of the $2 \mathrm{~mm}$ sieve and placed into a zip-lock bag containing seawater from the site. Juvenile bivalves were immediately placed on ice, frozen at the soonest possible opportunity and stored frozen at $-20^{\circ} \mathrm{C}$ until analysis.

\section{Sample preparation}

Prior to TE analysis, individuals were removed from the freezer and defrosted. The shells were sorted, and 45 to 50 individuals with a shell height of approximately $5 \mathrm{~mm}$ were selected for microchemical analysis from each site. Linear growth rates of

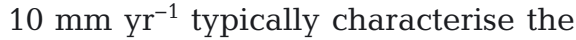
first $2 \mathrm{yr}$, suggesting that individuals selected were $<6$ mo in age (Adkins et al. 2014). Using stainless steel forceps, valves were split open, the flesh was removed and the shells were physically cleaned to remove any large adhering particles. Valves were placed into $50 \mathrm{ml}$ centrifuge tubes filled with deionised water (which was maintained at a resistivity of $<1 \mathrm{M} \Omega \mathrm{cm}$ ) and sonicated for 2 min to remove any remaining organic matter (Strasser et al. 2008). The water was drained, and the shells were allowed to air dry. Finally, the valves were mounted onto microscope slides by placing a bed of adhesive putty on the microscope slides and placing the left valve of each individual onto this base.

\section{Laser ablation inductively coupled plasma mass spectrometry}

Elements within juvenile shells were analysed by laser ablation inductively coupled plasma mass spectrometry (LA-ICP-MS). All analyses were conducted with a New Wave deep ultraviolet (193 nm) excimer laser ablation system (Electro Scientific Industries) coupled to an Agilent 7700 ICP-MS (Agilent Technologies). Two spots were ablated on each shell, one located approximately $50 \mu \mathrm{m}$ from the shell's most recently formed edge (the ventral margin) and one located approximately halfway between the ventral margin and the umbo. The approximate location of analyses is shown in Fig. 2. Shells were ablated with a laser spot size of $100 \mu \mathrm{m}$, a repetition rate of $5 \mathrm{~Hz}$ and laser power of $65 \%$. The dwell time was $45 \mathrm{~s}$. Two analyses of the NIST 610 glass standards were performed prior to and at the completion of each analytical session as well after every 25 laser spots performed to correct for elemental fractionation and machine drift. Gas flows and voltages were optimised to maximise sensitivity and signal stability while maintaining an oxide reduction ratio of less than $2 \%$. This was achieved by monitoring the thorium:thorium oxide ratios. Full LA-ICP-MS operating parameters are listed in Table 1. 


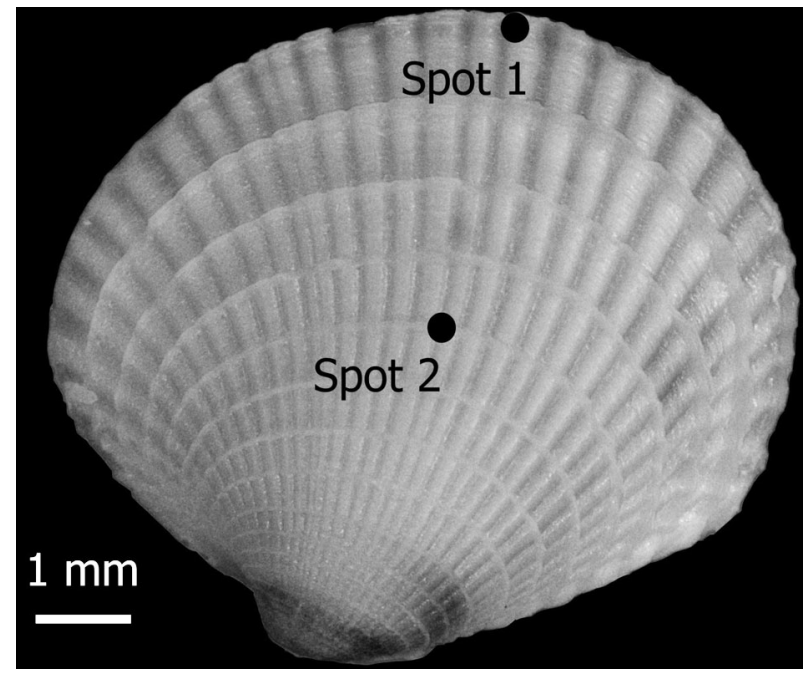

Fig. 2. Locations at which LA-ICP-MS spot analyses were performed on juvenile Austrovenus stutchburyi. Black spots mark analytical locations on the shell

The internal precisions of the TE:Ca ratios (\% 2 SD relative) of the LA-ICP-MS were calculated from the NIST 610 standard analyses performed in each analytical session. Internal precisions for TE: $\mathrm{Ca}$ analyses were $\mathrm{Sr}: \mathrm{Ca} \pm 7 \%, \mathrm{Zn}: \mathrm{Ca} \pm 6 \%, \mathrm{Mn}: \mathrm{Ca} \pm 5 \%, \mathrm{Fe}: \mathrm{Ca}$ $\pm 18 \%, \mathrm{~B}: \mathrm{Ca} \pm 6 \%, \mathrm{Ba}: \mathrm{Ca} \pm 4 \%, \mathrm{~V}: \mathrm{Ca} \pm 5 \%, \mathrm{Mg}: \mathrm{Ca}$ $\pm 5 \%, \mathrm{U}: \mathrm{Ca} \pm 6 \%, \mathrm{La}: \mathrm{Ca} \pm 6 \%, \mathrm{Al}: \mathrm{Ca} \pm 5 \%$, Co: $\mathrm{Ca}$ $\pm 5 \%$, Ce: $\mathrm{Ca} \pm 6 \%, \mathrm{~Pb}: \mathrm{Ca} \pm 6 \%, \mathrm{Y}: \mathrm{Ca} \pm 7 \%, \mathrm{Cu}: \mathrm{Ca}$ $\pm 14 \%$, Li:Ca $\pm 6 \%$, Ti:Ca $\pm 5 \%, \mathrm{Ni}: \mathrm{Ca} \pm 6 \%$. Detection limits were calculated as the ratio of 3 times the standard deviation of the background to the NIST 610 analyses. The detection limits ( $\mu \mathrm{mol}: \mathrm{mol})$ were Sr:Ca 2.1, Zn:Ca 1.6, Mn:Ca 1.3, Fe:Ca 1.3, B:Ca 0.2, Ba:Ca 3.3, V:Ca 1.2, Mg:Ca 0.6, U:Ca 5.8, La:Ca 3.4, Al:Ca 0.7, Co:Ca 1.4, Ce:Ca 3.4, Pb:Ca 5.1, Y:Ca 2.1, Cu:Ca 1.6, Li:Ca 0.2, Ti:Ca 1.2, Ni:Ca 1.4.

\section{Ablation procedure}

No chemical pre-cleaning was performed; rather, a pre-ablation technique was performed to remove contaminants from the shell surface. This procedure has previously been used when examining biogenic carbonates (Creech et al. 2010, Bolton et al. 2011, Marr et al. 2011). In these studies, inspection of the ablation profile was used to establish the removal of the contaminated surface veneer through laser ablation and to establish that the structure of interest was being ablated. In the present study, particular attention was paid to the Mg:Ca ratio, as organic material has been shown to be enriched in Mg relative to the carbonate crystal matrix (Schöne et al. 2010). A typical ${ }^{25} \mathrm{Mg}$ ablation profile is shown in Fig. 3. Organic matter was deemed to have been removed when the ${ }^{25} \mathrm{Mg}$ ablation counts stabilised after an initial rapid decrease. The drop in the ${ }^{25} \mathrm{Mg}$ ablation counts always occurred within the first $10 \mathrm{~s}$ of analysis; therefore, this period was excluded from calculations of elemental concentrations. ${ }^{43} \mathrm{Ca}$ ablation counts per second were also monitored throughout analysis to ensure that shell material was being analysed and that ablation of adhesive putty and glass slides did not accidentally occur. The final $10 \mathrm{~s}$ of the laser ablation signal was also excluded to prevent complications associated with the drop in laser power at the end of the dwell time.

Due to the exclusion of the first and last $10 \mathrm{~s}$ of ablation data, only the middle $25 \mathrm{~s}$ of data was included in calculations of elemental concentrations. Data from the middle $25 \mathrm{~s}$ of the laser dwell period were then background corrected by subtracting the background average counts prior to analysis from the ablation average counts. The background-corrected counts per second were converted to TE:Ca ratios and normalised using the most recently published NIST 610 values (Jochum et al. 2005) to correct for instrumental drift and elemental fractionation. Finally, TE:Ca ratios were converted to $\mu \mathrm{mol}: \mathrm{mol}$ ratios, which were used in all statistical analyses.

\section{Statistical analyses}

To determine variation in elemental fingerprints, a discriminant function analysis (DFA) was performed in JMP 12.0 software (SAS Institute). Intra-shell variation in elemental fingerprints was examined using

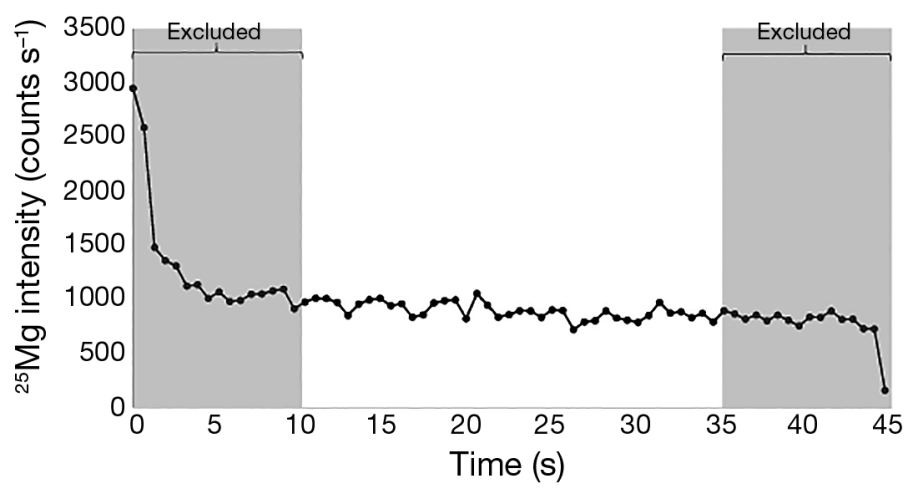

Fig. 3. Representative Mg ablation profile during a $45 \mathrm{~s}$ analysis showing the excluded pre- and post-ablation periods 
the TE:Ca ratios of each individual laser spot (2 spots within each shell). Correlation matrices were generated for each site/spot using MANOVA, and due to differing covariance estimates among sites, a quadratic DFA (Q-DFA) was performed. As non-normality was detected, data were rank transformed (Bello 1993) prior to the Q-DFA. The mean canonical scores for each spot were calculated to show how elemental fingerprints varied within each shell collected from each of the sampling sites.

To examine inter-site differences, the mean of the 2 spots performed on each shell was used to obtain a single measurement of TE:Ca ratios for each $A$. stutchburyi shell analysed. The mean of the 2 spots (Fig. 2) was used to reduce the effects of small temporal fluctuations in shell chemistry. Correlation matrices were generated for each site using MANOVA, and a Q-DFA was performed due to differing covariances. Data were also rank transformed due to non-normality. The Q-DFA was performed stepwise by first running the analysis on all elemental ratios and recording the overall classification success. Next, the elemental ratio with the least discriminatory influence was removed, and the Q-DFA was run again with the difference in classification success noted. This was repeated for all elemental ratios to identify the point at which a major decrease in the classification success was observed and thus which combination of elements could provide successful discrimination of sites. A classification matrix was generated to gauge the success of the Q-DFA in assigning shells back to their site of collection based on elemental ratios, and mean canonical scores were calculated.

When performing DFAs, Meyers et al. (2013) have suggested that, to be statistically robust, the sample size (n) for the smallest group (i.e. site) should at least exceed the number of predictor variables (i.e. elemental ratios) used. In this case, the number of predictor variables was 19 overall, 10 of which contributed to classification success, and the smallest sample size was 38 (from the Waipu site).

Univariate tests were performed on the 4 elements which were responsible for the largest portion of classification success in the Q-DFA examining intersite differences. A 1-way ANOVA was performed on the Sr:Ca, Mn:Ca, Zn:Ca and Fe:Ca ratios. The data were examined, and as they did not fit the assumptions of normality, data were log transformed. Outliers which fell more than \pm 3 SD from the mean were removed. Tukey's HSD tests were then performed on those elemental ratios which differed significantly between sites to determine pairwise site differences.

\section{RESULTS}

\section{Intra-shell variation}

The Q-DFA examining the intra-shell differences in elemental fingerprints was able to assign shells to their collection location with $92 \%$ accuracy and to the collection location/spot with $82 \%$ accuracy. These results, as well as the plot of the canonical scores (Fig. 4), indicate that although intra-shell differences did exist in the elemental fingerprints of Austrovenus stutchburyi, these differences did not mask inter-site differences.

\section{Spatial differences in trace elemental fingerprints}

The Q-DFA performed using the mean of the 2 spots analysed on each shell was able to correctly assign juvenile $A$. stutchburyi to their site of collection with $99 \%$ accuracy (the classification success rates expected by chance are $8.3 \%$ ) (Table 2; Fig. 5). This result was achieved with the stepwise inclusion of 10 elemental ratios (Sr:Ca, Zn:Ca, Mn:Ca, Fe:Ca, $\mathrm{B}: \mathrm{Ca}, \mathrm{Ba}: \mathrm{Ca}, \mathrm{V}: \mathrm{Ca}, \mathrm{Mg}: \mathrm{Ca}, \mathrm{U}: \mathrm{Ca}$ and $\mathrm{La}: \mathrm{Ca}$ ) into the Q-DFA model (Table 3). The high overall accuracy of the Q-DFA was also reflected in the individual site classification success rates, which ranged from 95 to $100 \%$ (Table 2). Sites within the harbour located as close together as $1.2 \mathrm{~km}$ (Snake Bank and One Tree Point) were able to be reliably distinguished from each other with $100 \%$ accuracy. The maximum dis-

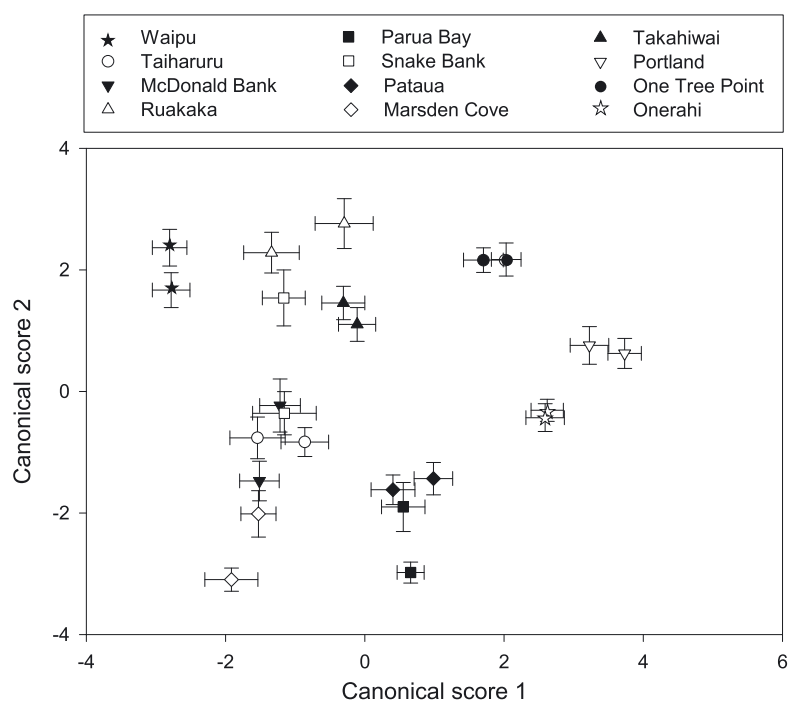

Fig. 4. Mean canonical scores $( \pm 95 \% \mathrm{CI})$ from the quadratic discriminant function analysis investigating variation in the elemental fingerprints between the 2 spots performed on each shell 
Table 2. Classification matrix from the quadratic discriminant function analysis of trace element:calcium ratios of juvenile Austrovenus stutchburyi shells collected from the Whangarei region in March 2014. Sites are arranged from west to east and grouped according to the region from which they were collected. Values in bold indicate the number of individuals for which the actual and predicted site were the same

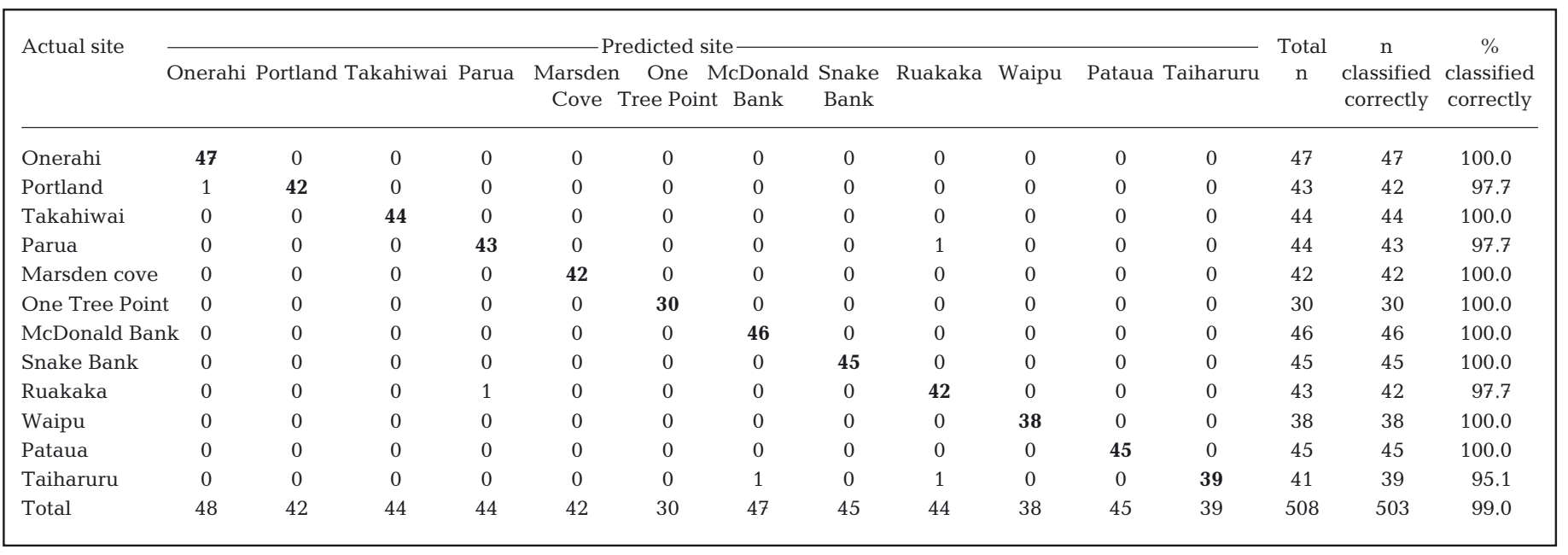

tance between sites which were able to be distinguished based on their trace elemental fingerprints was $35 \mathrm{~km}$ (Waipu and Portland). Inter-estuary differences in trace elemental fingerprints were also pronounced, and only 3 individuals $(0.7 \%$ of those collected) were classified to an estuary other than that from which they were collected $(21 \%$ would be expected by chance). The smallest distance between estuaries in this study was $1 \mathrm{~km}$ (Pataua and Taiharuru); despite their proximity, the Q-DFA was $100 \%$ successful at distinguishing between them, with no cross-classification errors occurring.

The results of the stepwise variable selection procedure showed that although $10 \mathrm{TE}: \mathrm{Ca}$ ratios were able to produce a DFA model which classified settled shells to their site of collection with $99 \%$ accuracy, fewer ratios contributed the majority of discriminating power of the model (Table 3). Sr was the primary driver of spatial variation, with $43 \%$ of individuals classified correctly using only the $\mathrm{Sr}$ :Ca ratio. The $\mathrm{B}: \mathrm{Ca}$ and $\mathrm{Mn}$ :Ca ratios were also important discriminators for the accuracy of the model, contributing to 20 and $15 \%$, respectively, of the model's discriminating power, bringing the total classification success to $80 \%$ using only these 3 elements.

Results of the ANOVA indicated that significant differences existed between sites in the 4 elemental ratios responsible for the majority of classification success (Table 4) (Sr:Ca p $<0.01, \mathrm{Mn}: \mathrm{Ca} \mathrm{p}<0.01$, $\mathrm{Zn}:$ Ca $\mathrm{p}<0.01$, Fe:Ca p < 0.01). Tukey's HSD post hoc tests indicated that significant pairwise differences existed between most sites in the TE:Ca ratios examined (Table 5). The proximity of sites to each other did not appear to influence whether pairwise differences in the $\mathrm{Sr}: \mathrm{Ca}, \mathrm{Mn}: \mathrm{Ca}, \mathrm{Zn}: \mathrm{Ca}$ or Fe:Ca ratios were detected. Parua Bay and Snake Bank, for example, are separated by only $1.3 \mathrm{~km}$ but differed significantly in all TE:Ca ratios with the exception of Fe:Ca. In contrast, Tahiruru and Onerahi were located the furthest distance apart of any 2 sites in this study but did not differ significantly in their $\mathrm{Sr}: \mathrm{Ca}, \mathrm{Mn}: \mathrm{Ca}$ or Fe:Ca ratios.

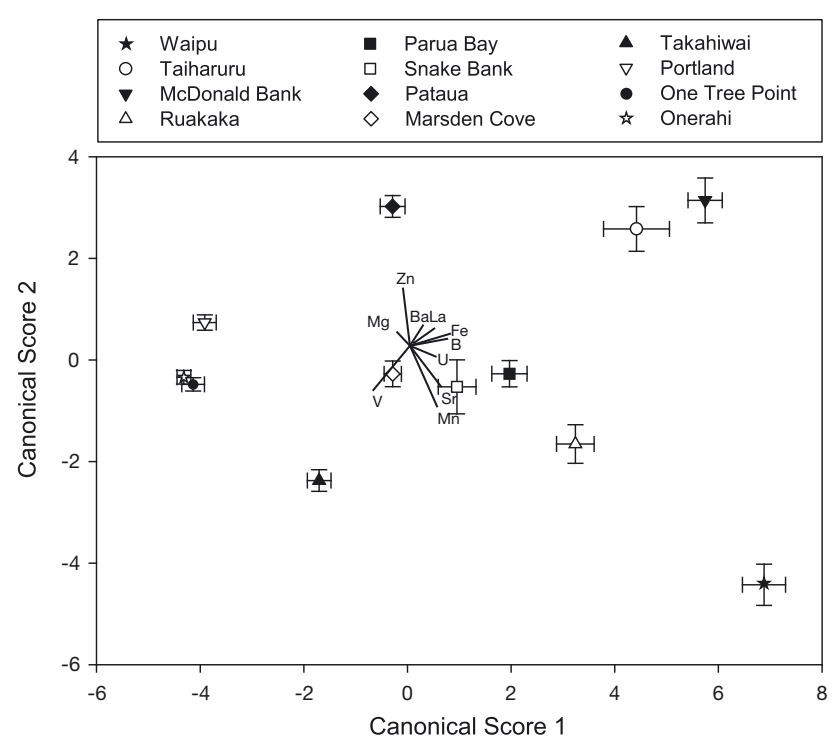

Fig. 5. Mean canonical scores $( \pm 95 \% \mathrm{CI})$ from the quadratic discriminant function analysis (Q-DFA) examining the intersite differences in mean trace elemental fingerprints of both analytical locations within each shell. Overlaid elemental vectors show how each of the elements included in the Q-DFA is driving differentiation between sites 
Table 3. Results of the stepwise variable selection procedure of the quadratic discriminant function analysis model comparing elemental ratios of Austrovenus stutchburyi. Note: shaded elements indicate those used to produce the classification matrix in Table 2

\begin{tabular}{|lcc|}
\hline $\begin{array}{l}\text { Elemental } \\
\text { ratio }\end{array}$ & $\begin{array}{c}\text { Total \% } \\
\text { classified correctly }\end{array}$ & $\begin{array}{c}\text { Individual \% } \\
\text { classified correctly }\end{array}$ \\
\hline $\mathrm{Sr}: \mathrm{Ca}$ & 42.91 & 42.91 \\
$\mathrm{Zn}: \mathrm{Ca}$ & 65.16 & 22.25 \\
$\mathrm{Mn}: \mathrm{Ca}$ & 80.91 & 15.75 \\
$\mathrm{Fe}: \mathrm{Ca}$ & 88.19 & 7.28 \\
$\mathrm{~B}: \mathrm{Ca}$ & 91.14 & 2.95 \\
$\mathrm{Ba}: \mathrm{Ca}$ & 93.7 & 2.56 \\
$\mathrm{~V}: \mathrm{Ca}$ & 95.47 & 1.77 \\
$\mathrm{Mg}: \mathrm{Ca}$ & 97.05 & 1.58 \\
$\mathrm{U}: \mathrm{Ca}$ & 98.42 & 1.37 \\
$\mathrm{La}: \mathrm{Ca}$ & 99.02 & 0.6 \\
$\mathrm{Al}: \mathrm{Ca}$ & 99.21 & 0.19 \\
$\mathrm{Co}: \mathrm{Ca}$ & 99.61 & 0.4 \\
$\mathrm{Ce}: \mathrm{Ca}$ & 99.61 & 0 \\
$\mathrm{~Pb}: \mathrm{Ca}$ & 99.61 & 0 \\
$\mathrm{Y}: \mathrm{Ca}$ & 99.8 & 0.19 \\
$\mathrm{Cu}: \mathrm{Ca}$ & 99.8 & 0 \\
$\mathrm{Li}: \mathrm{Ca}$ & 100 & 0.2 \\
$\mathrm{Ti}: \mathrm{Ca}$ & 100 & 0 \\
$\mathrm{Ni}: \mathrm{Ca}$ & 100 & 0 \\
& & \\
\hline
\end{tabular}

\section{DISCUSSION}

The results of this study demonstrate (1) that trace elemental fingerprinting techniques can be used to differentiate between Austrovenus stutchburyi populations over small intra- and inter-estuary scales (as small as $1.2 \mathrm{~km}$ ) relevant to their management; (2) that although intra-shell variation in elemental fingerprints exists, inter-site differences are maintained regardless of the location of the analysis within settled shell; and (3) that an elemental suite consisting of $10 \mathrm{TE}$ : Ca ratios provides optimal classification success, with the $\mathrm{Sr}: \mathrm{Ca}, \mathrm{Mn}: \mathrm{Ca}$ and $\mathrm{Zn}: \mathrm{Ca}$ ratios together providing over $80 \%$ classification success.

\section{Intra-shell variation}

The results of the Q-DFA investigating variation in the trace elemental fingerprints within A. stutchburyi shells demonstrated that although intra-shell variation in trace elemental fingerprints existed, this was not sufficient to mask inter-site differences. It is likely that environmental stability contributed to the lack of variation in TE:Ca ratios within each shell. Shell analysed in this study was likely deposited over approximately $3 \mathrm{mo}$ (using linear growth rates of $10 \mathrm{~mm} \mathrm{yr}^{-1}$ from Adkins et al. 2014). Shell material was, therefore, likely deposited over the austral summer, when the environmental conditions which may influence elemental incorporation into bivalve shell (i.e. temperature and salinity) were stable (Beer et al. 2011, Poulain et al. 2015). Mean air temperatures from December 2013 to February 2014 ranged from 19.1 to $20.1^{\circ} \mathrm{C}$ (NIWA 2016). These results imply that shell material deposited at different times over a period of environmental stability can be compared, therefore reducing the need for frequent sampling to maintain up-to-date data on elemental fingerprints between sites (Carson et al. 2013).

These results also suggest that age effects did not influence the incorporation of TEs into settled juvenile shell. Further work, however, should be performed prior to the extension of this finding to the prodissoconch. There are a number of differences between settled shell and prodissoconch shell which may hinder their comparison. Physical changes in the environment as a shell transitions from a pelagic to an infaunal lifestyle may result in different elements being available for incorporation into growing shell. It has previously been demonstrated that differences in the incorporation of elements to bivalve shell vary between larval and recruited shell (Zacherl et al. 2009). It has also been found that the diet of individuals may influence the uptake of elements into bivalve shell (Thebault et al. 2009). Furthermore, it is

Table 4. Mean elemental levels ( $\mu \mathrm{mol}: \mathrm{mol} \pm \mathrm{SE}$ ) of the 4 elements responsible for the majority of the classification success of the quadratic discriminant function analysis. The p-value for all ANOVAs examining inter-site differences in elemental ratios was $<0.01$

\begin{tabular}{|lrcrc|}
\hline Collection site & Mn:Ca & Sr:Ca & Zn:Ca & Fe:Ca \\
\hline Waipu & $0.6 \pm 0.05$ & $1455.8 \pm 36.5$ & $6.3 \pm 0.4$ & $861.9 \pm 46.3$ \\
Taiharuru & $5.1 \pm 0.9$ & $2090.2 \pm 28.9$ & $6.5 \pm 0.7$ & $1316.3 \pm 111.1$ \\
McDonald Bank & $3.0 \pm 0.2$ & $2176.0 \pm 44.5$ & $2.5 \pm 0.2$ & $531.6 \pm 39.4$ \\
Ruakaka & $27.2 \pm 4.5$ & $1445.2 \pm 34.7$ & $12.4 \pm 2.2$ & $901.0 \pm 59.5$ \\
Parua Bay & $28.7 \pm 3.7$ & $1851.1 \pm 46.9$ & $19.7 \pm 1.3$ & $488.6 \pm 29.9$ \\
Snake Bank & $2.3 \pm 0.2$ & $2173.6 \pm 78.6$ & $8.1 \pm 1.1$ & $703.2 \pm 44.3$ \\
Pataua & $3.3 \pm 0.3$ & $2528.8 \pm 23.9$ & $1.7 \pm 0.1$ & $573.2 \pm 33.8$ \\
Marsden Cove & $1.5 \pm 0.0$ & $2605.8 \pm 25.8$ & $20.1 \pm 1.5$ & $280.9 \pm 6.4$ \\
Takahiwai & $6.2 \pm 1.4$ & $1755.5 \pm 25.8$ & $31.2 \pm 2.8$ & $975.7 \pm 86.5$ \\
Portland & $36.7 \pm 5.2$ & $2048.3 \pm 18.0$ & $8.3 \pm 0.9$ & $1395.2 \pm 154.0$ \\
One Tree Point & $24.3 \pm 1.5$ & $2030.4 \pm 21.6$ & $7.2 \pm 0.6$ & $1379.3 \pm 103.2$ \\
Onerahi & $10.4 \pm 0.7$ & $1968.7 \pm 20.4$ & $19.9 \pm 1.1$ & $797.1 \pm 34.8$ \\
\hline
\end{tabular}




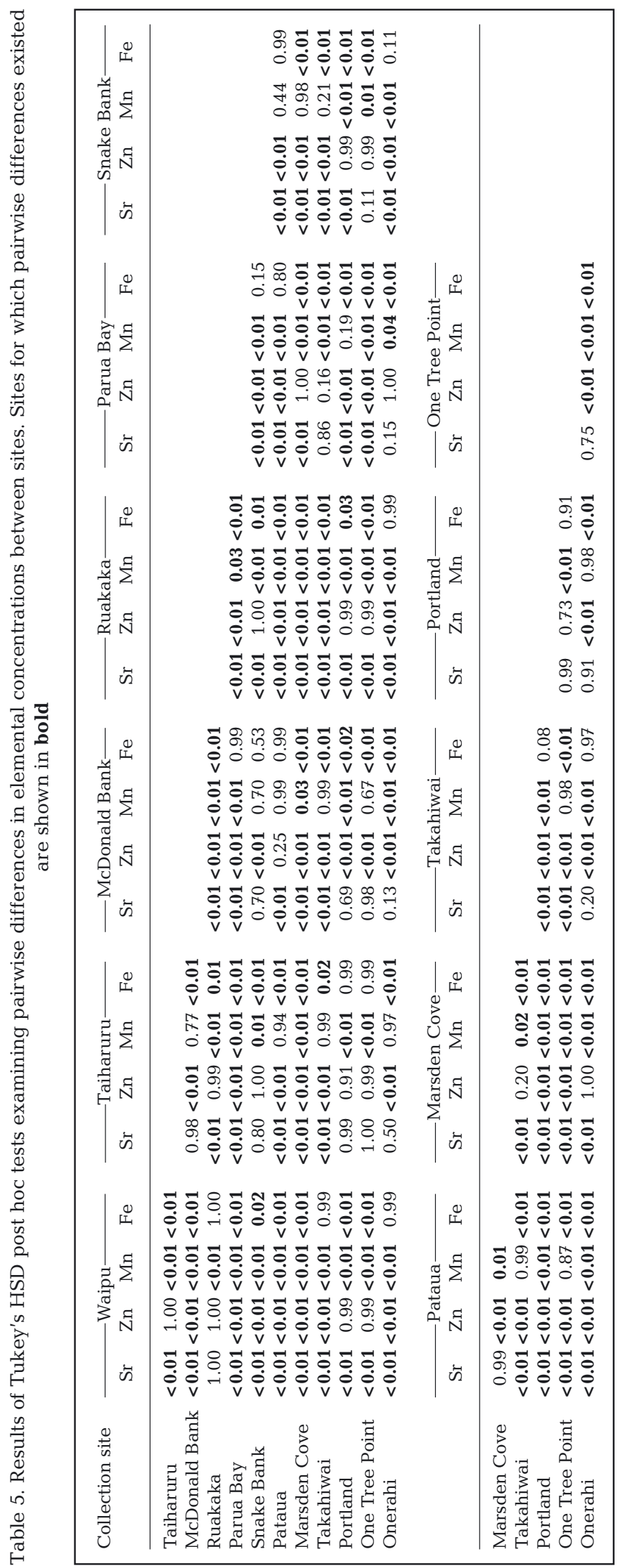

possible that prodissoconch shell initially consists primarily of amorphous calcium carbonate (ACC), which later transitions to aragonite (Weiss et al. 2002). Both differences in the structure of ACC as well as changes as this precursor transitions to aragonite have the potential to prevent comparisons being made between prodissoconch and settled shell material (Weiss et al. 2002).

Future studies examining within-shell variation should now focus on differences between juvenile shell material and prodissoconch shell material formed at the same location under constant environmental conditions. This will allow determination of whether settled shell can be used to infer the formation location of prodissoconch material and whether the natal location of individuals can be established without the need for labour-intensive outplanting methods such as those used by Carson et al. (2010) and Becker et al. (2007).

\section{Inter-site elemental differences}

Overall, the Q-DFA examining the spatial differences in the trace elemental fingerprints in settled shell was able to correctly assign shells to their collection location with $99 \%$ accuracy. This high classification success rate indicates that, even over small scales of only a few $\mathrm{km}$, trace elemental fingerprinting techniques can be used to differentiate between individuals collected from numerous locations within a single estuary as well as between closely located estuaries on the same stretch of coastline (Cathey et al. 2014). This strong spatial variation suggests that the classification of shell material deposited at unknown locations to its formation location based on its trace elemental fingerprint can occur with a high degree of confidence.

Although in previous studies utilising a similar approach classification success has reached $100 \%$ (Cathey et al. 2012), our study shows much higher classification success rates than the 60 to $70 \%$ generally achieved (e.g. Becker et al. 2005, Dunphy et al. 2011, Sorte et al. 2013). The spatial resolution at which sites can be distinguished from each other in the literature can be as low as $1 \mathrm{~km}$ (Cathey et al. 2014). The majority of studies, however, have examined differences in shell microchemistry between closely located estuaries or along open coastlines at much larger between-site distances (e.g. Dunphy et al. 2011, López-Duarte et al. 2012, Cathey et al. 2014, Davoren et al. 2015, DiFranco et al. 2015). Only Ricardo et al. (2015) previously examined how trace 
elemental fingerprints vary between sites located close to each other in a single estuary and were able to distinguish between sites located less than $1 \mathrm{~km}$ apart with over $80 \%$ accuracy. The advantage of the current study over Ricardo et al. (2015) is that both a higher number of sites were sampled and more individuals from each site were analysed.

Optimal classification success occurred with the inclusion of $10 \mathrm{TE}$ :Ca ratios into the DFA model. This information is valuable, as it limits the number of elements needing to be quantified in future geochemical fingerprinting studies on this species in this area. The 3 elements ( $\mathrm{Sr}, \mathrm{Zn}$ and $\mathrm{Mn}$ ) which dictated the majority of classification success are frequently used as part of the trace elemental suite in fingerprinting studies (e.g. Broadaway \& Hannigan 2012, Sorte et al. 2013, Cathey et al. 2014). In fact, even using only these elemental ratios achieves a classification success rate comparable to many other studies (e.g. Carson et al. 2007, Dunphy et al. 2011, Fodrie et al. 2011).

\section{Drivers of elemental variation}

The differences in the elemental composition of $A$. stutchburyi shells in this study were likely due to a number of factors. The incorporation of elements into bivalve shell has been shown to be influenced by biological and environmental factors such as growth rate, temperature, salinity or the concentration of elements in the surrounding environment (Lloyd et al. 2008, Beer et al. 2011, Tabouret et al. 2012, Poulain et al. 2015). As high-resolution temperature and seawater composition data are not available over the study area, it is only possible to speculate on why $\mathrm{Sr}, \mathrm{Zn}$ and $\mathrm{Mn}$ were responsible for the high classification rates observed.

Whangarei Harbour and its catchment are highly modified with urban, industrial and agricultural inputs present, which may have affected the trace elemental concentrations observed. Coastal geology and geography may also have influenced the incorporation of elements into A. stutchburyi shell. Weathering and erosion of rocks are important sources of TEs into marine systems and may influence TE:Ca ratios in shell (Lorens \& Bender 1980, Vitousek et al. 1999, Lloyd et al. 2008). From One Tree Point to the south, the coastal plain is primarily composed of Holocene alluvium, while at Pataua, sandstone and argillite rocks dominate the catchment. Whangarei Harbour's catchment is composed of a variety of lithologically distinct geological units, possibly con- tributing to the strong spatial differences in TE fingerprints observed within the estuary (Brook \& Edbrooke 2009).

The Sr:Ca ratio was responsible for the highest degree of classification success in the Q-DFA model investigating inter-site differences. This high discriminatory power of the Sr:Ca ratio suggests that Sr isotope ratios $\left({ }^{87} \mathrm{Sr} /{ }^{86} \mathrm{Sr}\right)$ might also be a powerful complementary discrimination tool along with TEs (Hobbs et al. 2005). Drivers of Sr:Ca variation over the study area are difficult to determine due to the number of processes which may control its incorporation into biogenic carbonate such as salinity and ambient Sr concentrations (Lorens \& Bender 1980, Zacherl et al. 2003, Heinemann et al. 2011, Poulain et al. 2015). The Sr:Ca ratio in A. stutchburyi did not follow a geographic pattern, nor was it related to possible anthropogenic activities at sites. The 2 sites with the highest Sr:Ca ratios, for example, were Pataua, located close to a freshwater input in a small village, and Marsden Cove, located close to a popular recreational marina. While freshwater input at Pataua may have driven the higher $\mathrm{Sr}: \mathrm{Ca}$ ratios, Waipu and Ruakaka were also located near freshwater inputs but had the lowest Sr:Ca ratios of all the study sites (Poulain et al. 2015).

$\mathrm{Zn}$ played a large role in the discriminatory power of the Q-DFA model. Heavy metals such as Zn may enter estuarine systems through runoff from anthropogenic sources. These heavy metals can then bind to sediments and be released, the equilibrium between the 2 being affected by complex factors such as salinity and pH (Hatje et al. 2003, Fukunaga \& Anderson 2011). In this study, however, the highest Zn:Ca ratios were found at Parua Bay and Takahiwai; both sites are dominated by agricultural grassland in their catchment area and are not located close to any potential sources of heavy metal contamination. In seawater, bound $\mathrm{Zn}$ may be released from sediments more readily than in fresh water, suggesting that salinity may affect its bioavailability (Hatje et al. 2003). This deabsorption of $\mathrm{Zn}$ from sediments may explain the low $\mathrm{Zn}$ :Ca ratios found in shell collected from Pataua, which is located in an estuary with significant freshwater input.

The $\mathrm{Mn}$ :Ca ratio was also responsible for a large portion of the discriminatory power of the Q-DFA. The availability of the $\mathrm{Mn}^{2+}$ ion may be influenced by microbial action or through input of high Mn sediments to the marine system (Klinkhammer \& McManus 2001, Husmann et al. 2012). Shells collected from Waipu were found to have the lowest $\mathrm{Mn}$ :Ca ratios. The Waipu River runs through a large 
area of agricultural farmland, from which runoff into the river may promote microbial activity. Microbes form $\mathrm{Mn}$ oxides and therefore remove $\mathrm{Mn}^{2+}$ ions from the surrounding environment, thereby reducing their availability to organisms, which may explain the low Mn:Ca ratios found at Waipu (Klinkhammer \& McManus 2001). The highest Mn:Ca ratios were found at Portland. The sediment in the upper harbour region in which this site is located is primarily mud (<63 $\mu \mathrm{m}$ grain size) (Millar 1980). Sediment with smaller grain sizes is more prone to resuspension than larger grains (Cornwell \& Porter 2009). Metals associated with suspended particulate matter may be an important exposure pathway for filter feeders such as A. stutchburyi (King et al. 2004). As sediment Mn concentrations may be much higher due to the binding of $\mathrm{Mn}$, this may explain the high $\mathrm{Mn}: \mathrm{Ca}$ ratios observed in shells from this site (Hatje et al. 2003).

Future studies should further investigate the drivers of inter-site variation so as to provide further insights into the potential temporal and spatial stability of the elemental fingerprints observed. Understanding the conditions which cause variation in elements between sites will aid in the selection of study sites where trace elemental fingerprinting may prove successful in tracking larval dispersal. It should also be noted that mean $\mathrm{Zn}: \mathrm{Ca}$ and $\mathrm{Mn}: \mathrm{Ca}$ ratios in some instances were near or below the detection limits of the ICP-MS ( $\mathrm{Zn}: \mathrm{Ca}$ at Pataua, Mn:Ca at Marsden Cove and Mn:Ca at Waipu). Due to the high number of elements used in the multivariate analysis, however, this is unlikely to have influenced the validity of the results obtained.

\section{CONCLUSIONS AND FUTURE DIRECTIONS}

Overall, there was a high degree of spatial variation in the elemental fingerprints of Austrovenus stutchburyi over the small inter- and intra-estuary scales investigated in this study. This represents an important step in the use of trace elemental fingerprinting to unravel the local-scale connectivity patterns required for the effective management of bivalve species.

Prior to the application of elemental fingerprints to track the dispersal of marine larvae in future studies, the use of a pre-ablation spot which is larger than the analysed spot should be investigated to determine if edge effects influence results (Fowler et al. 2015). A careful comparison of the results obtained from shell cleaned using the pre-ablation technique used here and other chemical cleaning techniques involving the use of hydrogen peroxide (e.g. Strasser et al. 2008) should also be undertaken to determine the effect of cleaning methodology. Furthermore, multiple sampling events should be incorporated to understand how elemental fingerprints change over seasonal or annual scales. Finally, future studies should examine if the ontogenetic and temporal intra-shell stability observed in settled shell of A. stutchburyi also extends to prodissoconch shell material. This will allow the comparison of prodissoconch and settled shell material to be made and allow inference of larval origins of settlers to validate biophysical models of larval dispersal in this area (Lundquist et al. 2009, Lundquist \& Broekhuizen 2012).

Acknowledgements. The authors thank Oliver Seymour, Sam Parkes and Graeme McKay for their assistance in the field. Stuart Morrow from the University of Auckland, Auckland Science Analytical Services, provided assistance with LA-ICP-MS analyses. Funding for this project was provided by New Zealand Ministry of Business, Innovation and Employment Coasts and Oceans Core Funding (Project No. COME1601) to NIWA. We also thank the 4 anonymous reviews whose feedback greatly improved earlier versions of the manuscript.

\section{LITERATURE CITED}

Abaunza P, Murta AG, Campbell N, Cimmaruta R and others (2008) Stock identity of horse mackerel (Trachurus trachurus) in the Northeast Atlantic and Mediterranean Sea: integrating the results from different stock identification approaches. Fish Res 89:196-209

Adkins SC, Marsden ID, Pirker JG (2014) Variation in population structure and density of Austrovenus stutchburyi (Veneridae) from Canterbury, New Zealand. J Shellfish Res 33:343-354

Almany GR, Connolly SR, Heath DD, Hogan JD and others (2009) Connectivity, biodiversity conservation and the design of marine reserve networks for coral reefs. Coral Reefs 28:339-351

> Becker BJ, Fodrie FJ, McMillan PA, Levin LA (2005) Spatial and temporal variation in trace elemental fingerprints of mytilid mussel shells: a precursor to invertebrate larval tracking. Limnol Oceanogr 50:48-61

Becker BJ, Levin LA, Fodrie FJ, McMillan PA (2007) Complex larval connectivity patterns among marine invertebrate populations. Proc Natl Acad Sci USA 104: 3267-3272

> Beer NA, Wing SR, Hu Y (2011) Physical versus biological control of element incorporation into biogenic carbonate: an in situ experiment in a New Zealand fjord. Mar Ecol Prog Ser 433:289-301

Bello AL (1993) On the performance of rank transform discriminant method in error-rate estimation. J Stat Comput Simul 48:153-165

Bolton A, Baker JA, Dunbar GB, Carter L, Smith EGC, Neil HL (2011) Environmental versus biological controls on $\mathrm{Mg} / \mathrm{Ca}$ variability in Globigerinoides ruber (White) from 
core top and plankton tow samples in the southwest Pacific Ocean. Paleoceanography 26:PA2219

- Broadaway BJ, Hannigan RE (2012) Elemental fingerprints used to identify essential habitats: Nantucket Bay scallop. J Shellfish Res 31:671-676

Brook FJ, Edbrooke SW (compilers) (2009) Geology of the Whangarei area. 1:250 000 geological map. GNS Science, Lower Hutt

Campana SE, Chouinard GA, Hanson JM, Fréchetc A, Bratteyd J (2000) Otolith elemental fingerprints as biological tracers of fish stocks. Fish Res 46:343-357

Carson HS (2010) Population connectivity of the Olympia oyster in southern California. Limnol Oceanogr 55: 134-148

> Carson HS, Morgan SG, Green PG (2007) Fine-scale chemical fingerprinting of an open coast crustacean for the assessment of population connectivity. Mar Biol 153: 327-335

Carson HS, López-Duarte PC, Rasmussen L, Wang D, Levin LA (2010) Reproductive timing alters population connectivity in marine metapopulations. Curr Biol 20:1926-1931

Carson HS, López-Duarte PC, Cook GS, Fodrie FJ, Becker BJ, DiBacco C, Levin LA (2013) Temporal, spatial, and interspecific variation in geochemical signatures within fish otoliths, bivalve larval shells, and crustacean larvae. Mar Ecol Prog Ser 473:133-148

> Cathey AM, Miller NR, Kimmel DG (2012) Microchemistry of juvenile Mercenaria mercenaria shell: implications for modeling larval dispersal. Mar Ecol Prog Ser 465: 155-168

Cathey AM, Miller NR, Kimmel DG (2014) Spatiotemporal stability of trace and minor elemental signatures in early larval shell of the northern quahog (hard clam) Mercenaria mercenaria. J Shellfish Res 33:247-255

Cornwell JC, Porter ET (2009) Biogeochemical factors. In: Petersen JE, Kennedy VS, Dennison WC, Kemp WM (eds) Enclosed experimental ecosystems and scale: tools for understanding and managing coastal ecosystems. Springer-Verlag, New York, NY, p 93-101

> Cowen RK, Sponaugle S (2009) Larval dispersal and marine population connectivity. Annu Rev Mar Sci 1:443-466

Creech JB, Baker JA, Hollis CJ, Morgans HEG, Smith EGC (2010) Eocene sea temperatures for the mid-latitude southwest Pacific from $\mathrm{Mg} / \mathrm{Ca}$ ratios in planktonic and benthic foraminifera. Earth Planet Sci Lett 299:483-495

> Cummings VJ, Pridmore RD, Thrush SF, Hewitt JE (1995) Post-settlement movement by intertidal benthic macroinvertebrates: Do common New Zealand species drift in the water column? NZ J Mar Freshw Res 29:59-67

> Cummings V, Hewitt J, Halliday J, MacKay G (2007) Optimizing the success of Austrovenus stutchburyi restoration: preliminary investigations in a New Zealand estuary. J Shellfish Res 26:89-100

Davoren GK, Woloschiniwsky CSA, Halden NM, Wang F (2015) Does otolith chemistry indicate the natal habitat of Newfoundland capelin Mallotus villosus? J Exp Mar Biol Ecol 464:88-95

> Delaney DG, Edwards PK, Leung B (2012) Predicting regional spread of non-native species using oceanographic models: validation and identification of gaps. Mar Biol 159:269-282

DiFranco A, Calò A, Pennetta A, DeBenedetto G, Planes S, Guidetti P (2015) Dispersal of larval and juvenile seabream: implications for Mediterranean marine protected areas. Biol Conserv 192:361-368
Dunphy BJ, Millet MA, Jeffs AG (2011) Elemental signatures in the shells of early juvenile green-lipped mussels (Perna canaliculus) and their potential use for larval tracking. Aquaculture 311:187-192

- Fodrie FJ, Becker BJ, Levin LA, Gruenthal K, McMillan PA (2011) Connectivity clues from short-term variability in settlement and geochemical tags of mytilid mussels. J Sea Res 65:141-150

Fowler AM, Macreadie PI, Bishop DP, Booth DJ (2015) Using otolith microchemistry and shape to assess the habitat value of oil structures for reef fish. Mar Environ Res 106: 103-113

> Fukunaga A, Anderson MJ (2011) Bioaccumulation of copper, lead and zinc by the bivalves Macomona liliana and Austrovenus stutchburyi. J Exp Mar Biol Ecol 396: 244-252

> Gawarkiewicz G, Monismith S, Largier J (2007) Observing larval transport processes affecting population connectivity: progress and challenges. Oceanography 20: 40-53

Gillanders BM, Sanchez-Jerez P, Bayle-Sempere J, RamosEspla A (2001) Trace elements in otoliths of the twobanded bream from a coastal region in the south-west Mediterranean: Are there differences among locations? J Fish Biol 59:350-363

- Grantham BA, Eckert GL, Shanks AL (2003) Dispersal potential of marine invertebrates in diverse habitats. Ecol Appl 13:108-116

Green M, Waldbusser GG, Hubazc L, Cathcart E, Hall J (2013) Carbonate mineral saturation state as the recruitment cue for settling bivalves in marine muds. Estuaries Coasts 36:18-27

Griffiths R (2012) Whāngārei Harbour Estuary Monitoring Programme. A technical report of the Northland Regional Council. Whangarei

Hatje V, Payne TE, Hill DM, McOrist G, Birch GF, Szymczak $R$ (2003) Kinetics of trace element uptake and release by particles in estuarine waters: effects of $\mathrm{pH}$, salinity, and particle loading. Environ Int 29:619-629

Hedgecock D, Barber PH, Edmands S (2007) Genetic approaches to measuring connectivity. Oceanography 20:70-79

Heinemann A, Hiebenthal C, Fietzke J, Eisenhauer A, Wahl M (2011) Disentangling the biological and environmental control of $M$. edulis shell chemistry. Geochem Geophys Geosystems 12:Q03009

> Hewitt JE, Cummings VJ (2013) Context-dependent success of restoration of a key species, biodiversity and community composition. Mar Ecol Prog Ser 479:63-73

> Hewitt JE, Thrush SF, Cummings VJ, Pridmore RD (1996) Matching patterns with processes: predicting the effect of size and mobility on the spatial distributions of the bivalves Macomona liliana and Austrovenus stutchburyi. Mar Ecol Prog Ser 135:57-67

Hobbs JA, Yin Q, Burton J, Bennett WA (2005) Retrospective determination of natal habitats for an estuarine fish with otolith strontium isotope ratios. Mar Freshw Res 56: 655-660

Husmann G, Abele D, Monien D, Monien P, Kriews M, Philipp EER (2012) The influence of sedimentation on metal accumulation and cellular oxidative stress markers in the Antarctic bivalve Laternula elliptica. Estuar Coast Shelf Sci 111:48-59

Inglis GJ, Hurren H, Oldman J, Haskew R (2006) Using habitat suitability index and particle dispersion models 
for early detection of marine invaders. Ecol Appl 16: 1377-1390

Jochum KP, Nohl U, Herwig K, Lammel E, Stoll B, Hofmann AW (2005) GeoReM : a new geochemical database for reference materials and isotopic standards. Geostand Geoanal Res 29:333-338

Jones GP, Planes S, Thorrold SR (2005) Coral reef fish larvae settle close to home. Curr Biol 15:1314-1318

Kim CK, Park K, Powers SP (2013) Establishing restoration strategy of eastern oyster via a coupled biophysical transport model. Restor Ecol 21:353-362

King CK, Dowse MC, Simpson SL, Jolley DF (2004) An assessment of five Australian polychaetes and bivalves for use in whole-sediment toxicity tests: toxicity and accumulation of copper and zinc from water and sediment. Arch Environ Contam Toxicol 47:314-323

Klinkhammer GP, McManus J (2001) Dissolved manganese in the Columbia River estuary: production in the water column. Geochim Cosmochim Acta 65:2835-2841

Kool JT, Moilanen A, Treml EA (2013) Population connectivity: recent advances and new perspectives. Landsc Ecol 28:165-185

> Largier JL (2003) Considerations in estimating larval dispersal distances from oceanographic data. Ecol Appl 13: 71-89

> Levin LA (2006) Recent progress in understanding larval dispersal: new directions and digressions. Integr Comp Biol 46:282-297

Lloyd DC, Zacherl DC, Walker S, Paradis G, Sheehy M, Warner RR (2008) Egg source, temperature and culture seawater affect elemental signatures in Kelletia kelletii larval statoliths. Mar Ecol Prog Ser 353:115-130

> López-Duarte PC, Carson HS, Cook GS, Fodrie FJ, Becker BJ, Dibacco C, Levin LA (2012) What controls connectivity? An empirical, multi-species approach. Integr Comp Biol 52:511-524

> Lorens R, Bender M (1980) The impact of solution chemistry on Mytilus edulis calcite and aragonite. Geochim Cosmochim Acta 44:1265-1278

Lundquist C, Broekhuizen N (2012) Predicting suitable shellfish restoration sites in Whangarei Harbour: larval dispersal modelling and verification. NIWA Client Report HAM2012-024, prepared for Ministry of Science and Innovation Envirolink Fund to Northland Regional Council. NIWA, Hamilton

> Lundquist CJ, Thrush SF, Oldman JW, Senior AK (2004) Limited transport and recolonization potential in shallow tidal estuaries. Limnol Oceanogr 49:386-395

Lundquist CJ, Oldman JW, Lewis MJ (2009) Predicting suitability of cockle Austrovenus stutchburyi restoration sites using hydrodynamic models of larval dispersal. N Z J Mar Freshw Res 43:735-748

> Marr JP, Baker JA, Carter L, Allan ASR, Dunbar GB, Bostock HC (2011) Ecological and temperature controls on $\mathrm{Mg} / \mathrm{Ca}$ ratios of Globigerina bulloides from the southwest Pacific Ocean. Paleoceanography 26:PA2209

Meyers LS, Gamst G, Guarino AJ (2013) Applied multivariate research: design and interpretation, 2nd edn. SAGE Publishing, Thousand Oaks, CA

Millar AS (1980) Hydrology and surficial sediments of Whangarei Harbour. MSc thesis, University of Waikato, Hamilton

> Moran AL, Marko PB (2005) A simple technique for physical marking of larvae of marine bivalves. J Shellfish Res 24: $567-571$
Morrison M (2003) A review of the natural marine features and ecology of Whangarei Harbour. NIWA Client Report AKL2003-122, prepared for Department of Conservation. NIWA, Auckland

Morton JE, Miller MC (1968) The New Zealand sea shore. Collins, London

Moueza M, Gros O, Frenkiel L (2006) Embryonic development and shell differentiation in Chione cancellata (Bivalvia, Veneridae): an ultrastructural analysis. Invertebr Biol 125:21-33

NIWA (National Institute of Water and Atmospheric Research) (2016) CliFlo: NIWA's national climate database on the web. http://cliflo.niwa.co.nz/ (accessed on 25 February 2016)

> Peteiro LG, Shanks AL (2015) Up and down or how to stay in the bay: retentive strategies of Olympia oyster larvae in a shallow estuary. Mar Ecol Prog Ser 530:103-117

Poulain C, Gillikin DP, Thebault J, Munaron JM and others (2015) An evaluation of $\mathrm{Mg} / \mathrm{Ca}, \mathrm{Sr} / \mathrm{Ca}$, and $\mathrm{Ba} / \mathrm{Ca}$ ratios as environmental proxies in aragonite bivalve shells. Chem Geol 396:42-50

> Ricardo F, Génio L, Leal MC, Albuquerque R and others (2015) Trace element fingerprinting of cockle (Cerastoderma edule) shells can reveal harvesting location in adjacent areas. Sci Rep 5:11932

Ross PM, Hogg ID, Pilditch CA, Lundquist CJ, Wilkins RJ (2012) Population genetic structure of the New Zealand estuarine clam Austrovenus stutchburyi (Bivalvia: Veneridae) reveals population subdivision and partial congruence with biogeographic boundaries. Estuaries Coasts 35:143-154

Schöne BR, Zhang Z, Jacob DP, Tütken T and others (2010) Effect of organic matrices on the determination of the trace element chemistry $(\mathrm{Mg}, \mathrm{Sr}, \mathrm{Mg} / \mathrm{Ca}, \mathrm{Sr} / \mathrm{Ca})$ of aragonitic bivalve shells (Arctica islandica)—comparison of ICP-OES and LA-ICP-MS data. Geochem J 44:23-37

Shanks AL (2009) Pelagic larval duration and dispersal distance revisited. Biol Bull 216:373-385

Sorte CJB, Etter RJ, Spackman R, Boyle EE, Hannigan RE (2013) Elemental fingerprinting of mussel shells to predict population sources and redistribution potential in the Gulf of Maine. PLOS ONE 8:e80868

Stephenson RL, Chanley PE (1979) Larval development of the cockle Chione stutchburyi (Bivalvia: Veneridae) reared in the laboratory. N Z J Zool 6:553-559

Strasser CA, Mullineaux LS, Walther BD (2008) Growth rate and age effects on Mya arenaria shell chemistry: implications for biogeochemical studies. J Exp Mar Biol Ecol 355:153-163

Tabouret H, Pomerleau S, Jolivet A, Pécheyran C and others (2012) Specific pathways for the incorporation of dissolved barium and molybdenum into the bivalve shell: an isotopic tracer approach in the juvenile great scallop (Pecten maximus). Mar Environ Res 78:15-25

> Tanner SE, Reis-Santos P, Cabral HN (2016) Otolith chemistry in stock delineation: a brief overview, current challenges and future prospects. Fish Res 173:206-213

> Thebault J, Chauvaud L, L'Helguen S, Clavier J and others (2009) Barium and molybdenum records in bivalve shells: geochemical proxies for phytoplankton dynamics in coastal environments? Limnol Oceanogr 54:1002-1014

Thrush SF, Hewitt JE, Norkko A, Nicholls PE, Funnell GA, Ellis JI (2003) Habitat change in estuaries: predicting broad-scale responses of intertidal macrofauna to sediment mud content. Mar Ecol Prog Ser 263:101-112 
Vitousek PM, Kennedy MJ, Derry LA, Chadwick OA (1999) Weathering versus atmospheric sources of strontium in ecosystems on young volcanic soils. Oecologia 121: 255-259

Walther BD, Thorrold SR (2006) Water, not food, contributes the majority of strontium and barium deposited in the otoliths of a marine fish. Mar Ecol Prog Ser 311:125-130

Weiss IM, Tuross N, Addadi L, Weiner S (2002) Mollusc larval shell formation: amorphous calcium carbonate is a precursor phase for aragonite. J Exp Zool 293:478-491

Williams JR, Smith MD, Mackay G (2006) Biomass survey

Editorial responsibility: Inna Sokolova,

Charlotte, North Carolina, USA and stock assessment of cockles (Austrovenus stutchburyi) on Snake Bank, Whangarei Harbour, 2006. N Z Fish Assess Rep 2006/38, Ministry of Fisheries, Wellington

Zacherl DC, Paradis G, Lea DW (2003) Barium and strontium uptake into larval protoconchs and statoliths of the marine neogastropod Kelletia kelletii. Geochim Cosmochim Acta 67:4091-4099

Zacherl DC, Morgan SG, Swearer SE, Warner RR (2009) A shell of its former self : Can Ostrea lurida Carpenter 1864 larval shells reveal information about a recruit's birth location? J Shellfish Res 28:23-32

Submitted: February 11, 2016; Accepted: September 7, 2016 Proofs received from author(s): October 21, 2016 